\title{
Manurial value of khat waste vermicompost from Awday, Harar town, Ethiopia
}

\author{
Hiranmai Yadav Rameshwar ${ }^{1}$ Anteneh Argaw ${ }^{1}$
}

Received: 29 May 2015/ Accepted: 16 March 2016/Published online: 1 April 2016

(c) The Author(s) 2016. This article is published with open access at Springerlink.com

\begin{abstract}
Purpose Catha edulis, commonly called as khat or chat is an evergreen plant cultivated in Ethiopia for its stimulant leaves. The young leaves are chewed as a part of social recreation and the older leaves along with the twigs are discarded. This forms the major part of municipal solid waste that is dumped in large quantity in Harar region. The present study was carried in Haramaya University, Ethiopia to decompose the khat wastes along with crop residues and different animal manures (cow dung, goat manure, poultry manure and swine manure) using the earthworm Eisenia foetida.

Methods The collected khat wastes along with crop residues and different animal manures were vermicomposted and assessed for nutrient contents using standard procedures.

Results The result of the experiment indicated that all the parameters were improved by the decomposition using earthworms and the $\mathrm{C} / \mathrm{N}$ ratio was within the limits that indicate the maturity of the compost. The organic carbon, organic matter, total nitrogen, phosphorus, copper, iron, zinc and manganese contents were analyzed and found to be improved after decomposition. The added crop residues and animal manures enhanced the decomposition process and manurial value of the khat leaf waste.
\end{abstract}

Hiranmai Yadav Rameshwar

mayahiranbt@gmail.com

Anteneh Argaw

antenehargaw@gmail.com

1 School of Natural Resources Management and Environmental Sciences, College of Agriculture and Environmental Sciences, Haramaya University, P.O. Box \#337, Dire Dawa, Ethiopia
Conclusion The nutrient content of the vermicomposts revealed khat to be a suitable substrate for vermicomposting thereby making efficient utilization of solid wastes. This can be an effective technology to reduce the solid waste and the resultant product can be used for improving soil fertility and crop production by the farmers.

Keywords Khat waste $\cdot$ Vermicomposting $\cdot$ Eisenia foetida · Animal manures - Recycling · Agriculture . Biofertilisers

\section{Introduction}

In Ethiopia, Horn of Africa, there are different organic wastes being produced annually by different activities like agriculture, agro industries, industries and municipal solid waste. Agricultural wastes are most preferably used as fodder or biofuel. The solid wastes are being dumped or burnt without proper recycling. The capital city of Ethiopia, Addis Ababa produces $0.5 \mathrm{~kg}$ per capita per day solid waste and the management of these wastes is difficult (Desta et al. 2014). It includes organic and inorganic wastes. There are different management problems encountered by the public and the municipal authorities (Regassa et al. 2011). Next to this, Bahir Dar, another major city of Ethiopia, also faces difficulty in handling of wastes generated daily (Lohri et al. 2014). The city of Debre Birhan produces much of organic waste that mainly includes food and kitchen wastes in urban solid waste and the recycling possibilities are yet to be exploited (Tyagi et al. 2014). Similarly, Debre Markos also faces the difficulty of management of solid wastes produced by the city (Tiwari and Tiwari 2012). Jimma city of Ethiopia produces a huge amount of waste that needs to be recycled (Getahun 
et al. 2012). Dessalegn et al. (2012) have suggested that the source separated municipal solid waste can be composted and used as manure. Shambu town of Ethiopia produces a large quantity of solid waste which needs to be managed effectively (Aboma and Reddy 2013). Dire Dawa city also produces a large quantity of municipal solid waste that could be converted into manure (Alemayehu 2013).

Khat is the export crop after coffee and oil seeds and plays a considerable role in the national economy. Its trade has a great influence on the farmers who cultivate them, the traders and exporters, and also have a high impact on the social, economic and health status of the society (Aden et al. 2006; Bongard et al. 2011). Catha edulis Forsk is an evergreen tree of Celastraceae family cultivated for its stimulant leaves primarily in East Africa. Presently Ethiopia, is the main producer and exporter of khat (Andualem 2002; Bongard et al. 2011; Ezekiel 2005; Yeshigeta and Abraham 2004; Wabel 2011). The culture of chewing khat has increased the demand for leaves but results in consequences of health and socio economic conditions (Dawit et al. 2005; Kandari et al. 2014). The leaves are chewed by a large population in Ethiopia (Dawit et al. 2005). The leaves are now common among students in different khat using countries in addition to motor vehicle and truck drivers and other working community (Yeshigeta and Abraham 2004; Reda et al. 2012; Alsanosy et al. 2013; Megerssa et al. 2014). The negative social and physical effects need to be considered while substituting the coffee cultivation by khat (Dechassa 2001). The Harar town of Ethiopia also produces large quantity of municipal solid waste. Major portion of it is khat waste discarded by users and exporters. The waste production is also enormous that needs proper disposal mechanism. Figure 1 shows the cultivation of khat in different parts of Ethiopia.
The khat is now cultivated in almost one-third area of coffee cultivation (Telake 2007). The transport facilities have expanded the khat utilization across the country (Gesese 2013; Andualem 2002; Guesh 2012). Khat is replacing coffee (Dube et al. 2014) and cereals (Taye and Jens 2003) in different parts of Ethiopia due to its economic benefits. It is bringing economy to the country, giving livelihood to a number of people by involving in different activities starting from agriculture to the export. The young leaves are chewed and the older leaves along with the twigs are discarded that forms the major part of municipal solid waste in Harar region which is a main place of khat cultivation, use and export. The town of Awadey known for its export of khat here adds a large quantity of solid waste as the older leaves are discarded along with twigs by export packagers and chewers of khat that are accumulated everyday in the town. Argaw et al. (2015) have shown that the khat waste could be a promising substrate for mushroom cultivation. It promises the utility of decomposition of the waste and converting it into manure. Different cities of Ethiopia producing bulk amount of municipal solid waste (organic waste) can be converted into organic manure by vermicomposting technology.

Vermicomposting is a bioconversion process where earthworms feed on the organic waste to produce more earthworms, vermicomposts and vermiwash as products. The vermicomposting technology is fast growing with its pollution-free, cost-effective and efficient nature to convert the rural and urban wastes into organic manure. Hemalatha (2012) has reported that the vermicomposts prepared from the partially decomposed fruit waste with paper and tannery industry sludge using Eudrillus eugeniae was found to be an effective method. The waste materials are being
Fig. 1 Commercially significant khat-growing regions in Ethiopia. The map is produced by superimposing the growing regions identified during field visits on existing roadmaps of the country. Source Gessesse (2013)

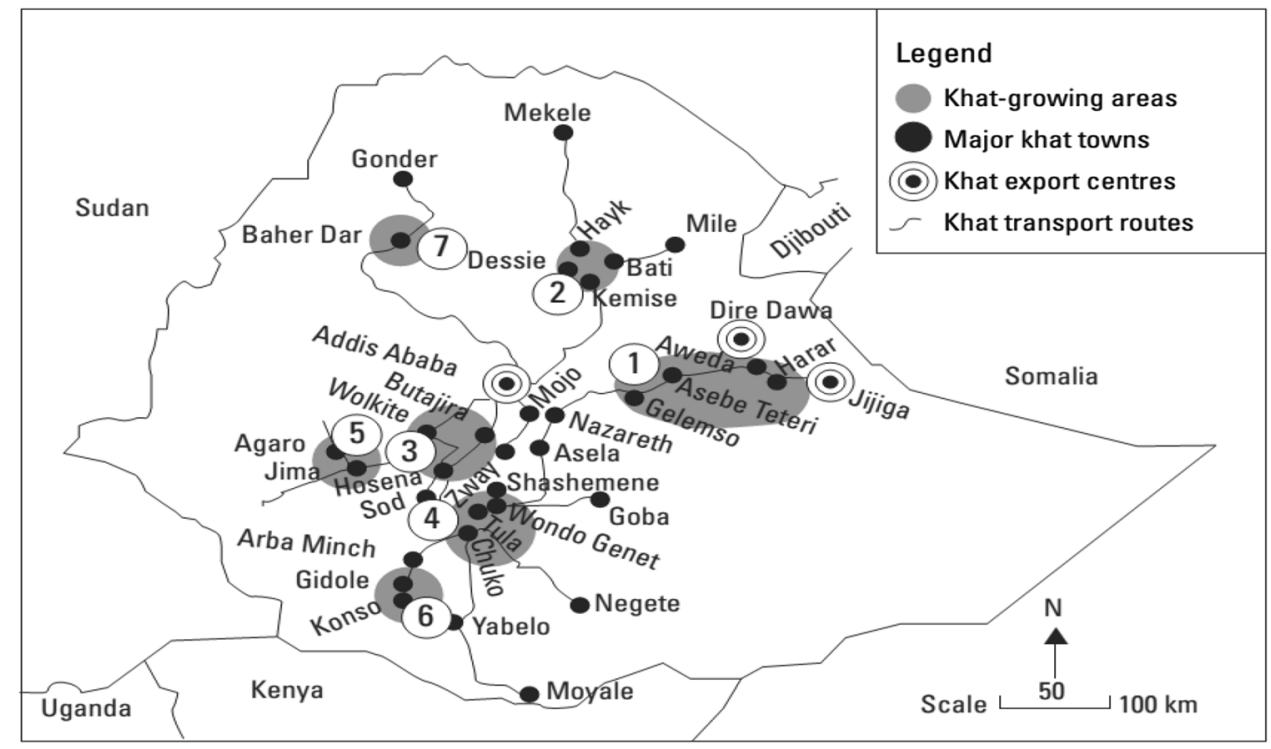


produced enormously that need to be managed without any adverse environmental impacts. There are many implications due to the accumulation of wastes in the soil. It gives immense odor due to the production of different gases, and pollutes the natural sources of water and also soil gets contaminated with pathogens. To overcome these difficulties, vermicomposting can be considered as an option that can reduce the pollution due to waste and produce valuable manure that can be used by farmers for improving soil fertility and crop production in a sustainable way. Gezahegn et al. (2012) have vermicomposted coffee husk, enset waste, khat waste and vegetable waste using the epigeic earthworm Eisenia foetida and found to be as a good option for improving solid waste management in Ethiopia and production of excellent biofertilisers for agronomic purposes. The analysis of vermicomposts revealed that there is an increase in nutrient content and reduced $\mathrm{C} / \mathrm{N}$ ratio. Thus, the vermicomposting plays a significant role in protecting environment as it uses the waste as raw material and building up the soil fertility and improving the soil health for sustainable agriculture.

Different species of earthworms are used for composting of animal, plant, pharmaceutical, food waste and sewage waste over vermicomposting periods ranging from 28 to 120 days using these worms. The predecomposition process of substrates for vermicomposting ranges with a varying temperature from 18 to $67{ }^{\circ} \mathrm{C}, \mathrm{pH} 5.9-8.3$ and moisture content up to $80 \%$. The vermicomposts and vermiwash produced are rich in nitrogen, phosphorus and potassium and can be applied to plants as biofertilisers (Manyuchi and Phiri 2013). Pigatin et al. (2016) have documented that co-vermicomposting of filter cake and orange peel with cattle manure is effective to reduce the wastes and utilize it for application in sustainable agriculture. Parthasarathi et al. (2016) have reported vermitechnology as an effective method of producing bioorganic fertilizer from cashew leaf litter and animal dungs. The present work was carried out to prepare vermicompost using khat waste from Awday town of Harar enriched by different combinations of farm wastes and organic manures.

\section{Methods}

\section{Description of the composting site}

Research field of RARE of Haramaya University campus is located in East Hararghe zone of western Oromiya National Regional State. The experimental field is located at $9^{\circ} 26^{\prime} \mathrm{N}$ latitude and $42^{\circ} 3^{\prime} \mathrm{E}$ longitude. The average altitude is about $1980 \mathrm{~m}$ asl. It is located in the semi-arid tropical belt of eastern Ethiopia and is characterized by a sub-humid type of climate with mean annual rainfall of $780 \mathrm{~mm}$. The site receives bimodal rainfall (March-April $25 \%$ rain and June-September $45 \%$ ). The mean monthly temperature ranges from 9.2 to $23.2^{\circ} \mathrm{C}$.

\section{Raw materials and composting process}

Catha edulis leaf wastes were collected from Awday town and cut into small pieces. The farm wastes were collected from fields of Haramaya University and they too were cut into smaller pieces of $2.5-5.0 \mathrm{~cm}$. The animal manures were obtained from agricultural farm of Haramaya University. The substrates in the ratio of 10:1:1 (weight in $\mathrm{kg}$ ) were used for the vermicomposting process as indicated below.

\begin{tabular}{l} 
Substrates and combinations used \\
in vermicomposting \\
\hline $\mathrm{T}_{1} \quad$ Catha edulis leaf wastes + farm wastes + cow dung \\
$\mathrm{T}_{2} \quad$ Catha edulis leaf wastes + farm wastes + goat manure \\
$\mathrm{T}_{3} \quad$ Catha edulis leaf wastes + farm wastes + poultry manure \\
$\mathrm{T}_{4} \quad$ Catha edulis leaf wastes + farm wastes + swine manure \\
\hline
\end{tabular}

\section{Vermicomposting process}

Cement tanks measuring $1 \mathrm{~m} \times 1 \mathrm{~m} \times 1 \mathrm{~m}$ were used for the vermicomposting. The substrates were mixed in 10:1:1 ratio. The mixtures were left with moisture for 30 days to degrade into smaller particles to make it palatable for the worms. The moisture and temperature were maintained by sprinkling water and turning the mixture. Composting earthworm species E. foetida commonly known as red worm were introduced after 30 days. The moisture content was maintained to $60-70 \%$ and the tanks were covered with moist jute bags to protect the worms from predators and prevent moisture loss. After 60 days of vermicomposting the samples were collected and analyzed for quality.

\section{Assessment of quality of the vermicomposts}

The collected samples were shade dried and processed as required for different physicochemical analyses in Soil Chemistry laboratory of Haramaya University, Dire Dawa, Ethiopia. Total organic carbon content in the samples was measured by Walkley and Black (1936) method and the organic matter was calculated by multiplying the percent organic carbon by 1.724 assuming that organic matter is composed of $58 \%$ carbon. The total nitrogen (TKN) was determined by micro-Kjeldahl method (Humphries 1956). The available phosphorus was estimated according to Jackson (1973). The micronutrients namely zinc, copper, 
Table $1 \mathrm{pH}$ and other nutrients value of composted khat waste. Source Mahabub (2008)

\begin{tabular}{ll}
\hline Parameter & Nutrient content \\
\hline $\mathrm{pH}$ & $7.28-7.78$ \\
Organic carbon (\%) & $11.51-15.32$ \\
Total nitrogen (\%) & $0.9-1.40$ \\
Available phosphorus (ppm) & $532-803$ \\
Potassium (ppm) & $6775-12,445$ \\
\hline
\end{tabular}

Table 2 Micronutrients present in fresh khat leaves. Source Minaleshewa et al. (2010)

\begin{tabular}{ll}
\hline Parameter & Nutrient content (RSD \%) \\
\hline Copper & 3.0 \\
Iron & 2.0 \\
Zinc & 2.4 \\
Manganese & 1.5
\end{tabular}

$R S D$ relative standard deviation $\%$

iron and manganese were assessed using atomic absorption spectrophotometer (Jackson 1973) method. The C/N ratio was calculated by dividing the total nitrogen by the organic carbon content. The nutrient value of the khat waste materials is indicated in Tables 1 and 2. This gives an idea about the substrate material that was utilized in the present study.

\section{Results}

\section{Nutrient status of khat vermicomposts}

The results obtained from the analysis of decomposed khat waste are recorded in Table 3. It exhibits the manurial value of the decomposed products in dry weight basis.

The contents of total organic carbon, organic matter, total nitrogen, available phosphorus, and micronutrients namely zinc, copper, iron and manganese varied among the treatments. The $\mathrm{C} / \mathrm{N}$ ratio of mature compost was within the limits and the end product was with earthy aroma and dark color.

The values of organic carbon (2.56 and $2.55 \%)$ and organic matter (4.33 and $4.38 \%$ ) obtained from the analyses were comparable in $\mathrm{T}_{2}(C$. edulis leaf wastes + farm wastes + goat manure) and $\mathrm{T}_{4} \quad(C$. edulis leaf wastes + farm wastes + swine manure), respectively. This could be due to the mineralization of animal manure applied in the treatments that enhanced the decomposition process and worm activity. The total nitrogen was high in $\mathrm{T}_{3}(1.56 \%)$, poultry manure-added vermicomposts. This could be attributed to the high nitrogen mineralization of volatile nitrogen in poultry manure. Available phosphorus was comparable among the treatments with a value of $60.49 \mathrm{ppm}$ in $\mathrm{T}_{2}$. A high value of copper (20.93 ppm), iron (443.33 ppm) and zinc (42.31 ppm) was also observed in $\mathrm{T}_{3}$ (with poultry manure). Manganese content was high in $\mathrm{T}_{4}(108.17 \mathrm{ppm})$. The organic carbon and organic matter were comparable in $T_{2}$ and $T_{4}$ whereas the nitrogen and micronutrients, copper, iron and zinc were high in $\mathrm{T}_{3}$, manganese was in $\mathrm{T}_{4}$. The $\mathrm{C} / \mathrm{N}$ ratio of the prepared vermicomposts ranged from 2.21 in $\mathrm{T}_{3}$ to 9.52 in $\mathrm{T}_{4}$. The values were found to be within the permissible limits for composted materials.

\section{Discussion}

Similar to the present study, the content of organic carbon (C) was $1.03 \%$ and organic matter was found to be $1.78 \%$ in Parthenium vermicomposted with cowdung using $E$. eugeniae earthworms (Hiranmai et al. 2012). Mekonnen and Argaw (2015) have also reported the beneficial effect of using khat waste after vermicomposting and applying for improving soil fertility and crop production. They decomposed khat waste with eucalyptus leaves and recorded extractable phosphorus $(0.57 \%)$ and total nitrogen $(1.4 \%)$ which is comparable to the present study. The values obtained for nitrogen were within the range of $0.51-1.61 \%$ as referred from Nagavellamma et al. (2004). Vermicomposting of vegetable wastes with cowdung and earthworm Eudrillus eugeniae were also found to improve

Table 3 Nutrient composition of Khat waste vermicomposted with farm residues and different animal manures

\begin{tabular}{lllllrlrrr}
\hline Parameters & $\begin{array}{l}\text { Organic } \\
\text { matter }(\%)\end{array}$ & $\begin{array}{l}\text { Organic } \\
\text { carbon }(\%)\end{array}$ & $\begin{array}{l}\text { Total } \\
\text { nitrogen }(\%)\end{array}$ & $\begin{array}{l}\text { Available } \\
\text { phosphorus (ppm) }\end{array}$ & $\begin{array}{l}\text { Copper } \\
(\mathrm{ppm})\end{array}$ & $\begin{array}{l}\text { Iron } \\
(\mathrm{ppm})\end{array}$ & $\begin{array}{l}\text { Zinc } \\
(\mathrm{ppm})\end{array}$ & $\begin{array}{l}\text { Manganese } \\
(\mathrm{ppm})\end{array}$ & $\begin{array}{l}\text { C/N } \\
\text { ratio }\end{array}$ \\
\hline $\mathrm{T} 1$ & 1.89 & 3.25 & 0.46 & 59.73 & 4.14 & 308 & 5.91 & 102.5 & 7.06 \\
$\mathrm{~T} 2$ & 2.56 & 4.33 & 0.52 & 60.49 & 2.07 & 106 & 6.81 & 100.2 & 8.12 \\
$\mathrm{~T} 3$ & 1.99 & 3.44 & 1.56 & 59.73 & 20.93 & 443 & 42.31 & 97.73 & 2.21 \\
$\mathrm{~T} 4$ & 2.55 & 4.38 & 0.46 & 59.73 & 4.37 & 236 & 10.8 & 108.17 \\
\hline
\end{tabular}

The values are means of triplicates 
the quality of end product in addition to reducing the waste quantity (Hiranmai and Vijayakumari 2002). The substrates used in vermicompost influence the stability of the final product of decomposition ( $\mathrm{Hu}$ et al. 2008). It was observed in earlier studies by Vijayakumari and Hiranmai (2004) that there was a gradual reduction in organic C content from fresh poultry droppings $(2.00 \%)$ to composted $(0.61 \%)$ and vermicomposted $(0.93 \%)$ samples. The organic matter content was also lower in composted poultry droppings $(1.05 \%)$ compared to fresh poultry droppings $(3.44 \%)$ and vermicomposted poultry droppings $(1.59 \%)$. The decomposition of poultry droppings using $E$. eugeniae was found to be beneficial in improving the quality to be used as organic manure (Vijayakumari and Hiranmai 2005).

Gezahegn et al. (2012) have vermicomposted coffee husk, enset waste, khat waste and vegetable waste using the epigeic earthworm E. foetida and found it as a good option for improving solid waste management in Ethiopia and production of excellent biofertilisers for agronomic purposes. Parthenium was vermicomposted with farm wastes and animal manures (cow dung, goat manure, poultry manure and swine manure) using E. foetida, the red worm. The $\mathrm{pH}$, organic carbon, organic matter, total nitrogen, phosphorus, potassium, sodium, calcium, magnesium, copper, iron, zinc and manganese contents were analyzed and found that these nutrient contents were improved. The results revealed the economic feasibility of the vermicompost (the organic manure) production and certify the ecofriendly nature of its technology (Hiranmai and Anteneh 2014; Hiranmai 2015).

The vermicompost prepared with cattle manure, food waste and paper was found to be rich in nutrients and vermicomposts contain plant growth-regulating materials like plant growth hormones and humic acids that can increase the germination, growth and yield of plants (Atiyeh et al. 2002; Arancon et al. 2006). Compost maturity is the level of decomposition that can be defined by the microbial biomass and decomposition of phytotoxic compounds in compost (Wu et al. 2000; Wu and Ma 2001). The co-composting by improved nutrient release reduces the cost and use of fertilizers.

Hiranmai and Anteneh (2015) have recorded C/N ratios to be within limits for paper vermicompost prepared using E. eugeniae. Hait and Tare (2011) have also reported C/N ratios less than 20 for activated sludge vermicompost. This indicates organic matter stabilization and reflects a satisfactory degree of decomposition and maturity of organic wastes. The loss of organic carbon as $\mathrm{CO}_{2}$ due to microbial respiration and addition of earthworm $\mathrm{N}$ excrement results in good $\mathrm{C} / \mathrm{N}$ ratios. Hemalatha (2012) has also reported that the vermicompost prepared from the partially decomposed fruit waste with paper and tannery industry sludge using $E$. eugeniae was found to be an effective method. The analysis of vermicomposts revealed that there is an increase in nutrient content and reduced $\mathrm{C} / \mathrm{N}$ ratio. Thus, the vermicomposting plays a significant role in protecting environment as it uses the waste as raw material and building up the soil fertility and improving the soil health for sustainable agriculture.

The substrate used in the present study was khat leaves, farm wastes and animal manures. This was to assess the efficiency of different manures and farm wastes in decomposition process. Ethiopia being agriculturebased country with farm and animals, the availability of wastes and manures varies in different regions. This can be used by the farmers for production of organic manures and used to maintain soil fertility and improve crop production. The country faces the soil fertility problems in different regions that can be managed by the use of available organic resources. In addition, the use of expensive chemical fertilizers that reduce the soil fertility can be minimized by developing the on-farm compost methods that help the farmers to use locally available resources.

As the obtained results show improvement in different parameters in different treatments, the study encourages the use of animal manure available to the farming community to produce vermicompost and use it in agriculture. Further use of different combinations of organic wastes may help to improve the quality of the product which has further application in crop production.

\section{Conclusion}

The present encourages the utility of locally available organic sources like organic municipal solid wastes, farm wastes and animal manures for production of vermicompost in developing countries like Ethiopia. This could be a good source of organic manure for farmers to reduce the chemical fertilizers and lead to sustainable agriculture. Production of compost or vermicompost from organic wastes can be considered as an entrepreneurship for the youth and farmers, thereby an economic and ecofriendly method can be developed. Further studies can be conducted to develop different integrated soil fertility management practices using the khat waste in combination with organic wastes available to the farmers.

Acknowledgments The authors are grateful to Haramaya University, Ethiopia for funding the project and field and the lab facilities provided to conduct the experiment.

Author contribution Both authors have contributed for the conduct of experiment and preparing the manuscript according to her/his expertise. 


\section{Compliance with ethical standards}

Conflict of interest The authors declare that there is no conflict of interest.

Open Access This article is distributed under the terms of the Creative Commons Attribution 4.0 International License (http://crea tivecommons.org/licenses/by/4.0/), which permits unrestricted use, distribution, and reproduction in any medium, provided you give appropriate credit to the original author(s) and the source, provide a link to the Creative Commons license, and indicate if changes were made.

\section{References}

Aboma FT, Reddy RU (2013) Community awareness of solid waste management practices: a case study from Ethiopia. Environ We Int J Sci Technol 8:55-59

Aden A, Dimba EAO, Ndolo UM, Chindia ML (2006) Socioeconomic effects of khat chewing in north eastern Kenya. East Afr Med J 8:69-73

Alemayehu M (2013) Analysis of solid waste management: the case of five selected kebeles in Dire Dawa city Administration. M.A. thesis, Haramaya University, Ethiopia

Alsanosy RM, Mahfouz MS, Gaffar AM (2013) Khat chewing among students of higher education in Jazan region, Saudi Arabia: prevalence, pattern, and related factors. Biomed Res Int. doi:10. $1155 / 2013 / 487232$

Andualem M (2002) The prevalence and socio-demographic characteristics of Khat chewing in Jimma town, South Western Ethiopia. Ethiop J Health 12:69-80

Anteneh A, Yemane G, Million F, Yoseph M, Mashilla D, Hiranmai YR (2015) Cultivation of three Pleurotus spp. on Khat (Catha edulis) leftover. National symposium on "Science, Technology and Innovation for National Development (STIND)" from 21st to 22nd March, 2014 at Wollega University, Nekemte

Arancon NQ, Edwards CA, Lee S, Byrne R (2006) Effects of humic acids from vermicomposts on plant growth. Eur J Soil Biol 46:65-69

Atiyeh RM, Lee S, Edwards CA, Arancon NQ, Metzger JD (2002) The influence of humic acids derived from earthworms-processed organic wastes on plant growth. Bioresour Technol 84:7-14

Bongard S, Absi M, Khalil N, Habori M (2011) Khat use and trait anger : effects on affect regulation during an acute stressful challenge. Research report University of Minnesota. Eur Addict Res 17:285-291

Dawit A, Asfaw D, Amare D, Ambaye D, Almaz A, Kelbessa U, Lemma K (2005) Khat chewing habit as a possible risk behavior for HIV infection: a case-control study. Ethiop J Health Dev 19:174-181

Dechassa L (2001) Khat (Catha edulis): botany, distribution, cultivation, usage and economics in Ethiopia (agriculturalist). UN-Emergencies Unit for Ethiopia Addis Ababa, June 2001

Dessalegn D, Hameed S, Seyoum L (2012) Evaluation of composting and quality of compost from the source separated municipal solid waste. J Appl Sci Environ Manag 16:5-10

Desta H, Worku H, Fetene A (2014) Assessment of contemporary municipal solid waste management in urban environment: the case of Addis Ababa, Ethiopia. J Environ Sci Technol 7:107-122

Dube DK, Hiranmai YR, Dube SK (2014) Why a shift from coffee to chat? A study of the Kersa woreda in Jimma zone of South Western Ethiopia. Res Humanit Soc Sci 4:176-182
Ezekiel G (2005) Leaf of Allah: khat and agricultural transformation in Harerge, Ethiopia. Afr Stud Rev 48:161-162

Gesese D (2013) Is khat a social ill? Ethical arguments about 'stimulant' among learned Ethiopians. ASC working paper 108, 2013

Gessesse D (2013) Favouring a demonized plant—khat and Ethiopian small holder enterprise. Curr Afr Issues Nord Afr Inst 51:9

Getahun T, Mengistie E, Haddis A, Wasie F, Alemayehu E, Dadi D, Van Gervan T, der Bruggen Van (2012) Municipal solid waste generation in growing urban areas in Africa: current practices and relation to socioeconomic factors in Jimma, Ethiopia. Environ Monit Assess 184:6337-6345

Gezahegn D, Seyoum M, Jorge D (2012) Vermicomposting as a sustainable practice to manage coffee husk, enset waste (Enset verticosum), khat waste (Catha edulis) and vegetable waste amended with cow dung using an epigeic earthworm Eisenia andrei (Bouch' 1972). Int J Pharm Tech Res 4:15-24

Guesh G (2012) Production and consumption trends of Khat in Ethiopia: a big business or a big worry. Adv Agric Sci Eng Res Sci Educ Dev Inst 2:414-427

Hait S, Tare V (2011) Optimizing vermistabilisation of waste activated sludge using vermicompost as a bulking material. Waste Manag 31:502-511

Hemalatha B (2012) Vermicomposting of fruit waste and industrial sludge. Int J Adv Eng Technol III(II):60-63

Hiranmai YR (2015) Assessment of different organic supplements for degradation of Parthenium hysterophorus by vermitechnology. J Environ Health Eng. doi:10.1186/s40201-015-0203-1

Hiranmai YR, Anteneh A (2014) Bioconversion of Parthenium hysterophorus into organic manure and its value addition using different animal manures. National symposium on Science, technology and innovations for national development from 21 to 22 March 2014, Wollega University, Ethiopia

Hiranmai YR, Anteneh A (2015) Utilisation of paper waste for production of vermicompost: a sustainable method to reduce waste and improve soil fertility. 5th national conference on 'environment and development' scheduled on 4-5 June, 2015 at Dilla University, Dilla

Hiranmai YR, Vijayakumari B (2002) Vermicomposting of vegetable wastes. XXV Indian Social Science Congress held at University of Kerala, Thiruvananthapuram, from 28th January to 1st February 2002, abstract, p 39

Hiranmai YR, Eyasu M, Vijayakumari B (2012) Bioconversion of Parthenium hysterophorus into valuable organic manure. In: Proceedings of the national conference on science, technology, and innovations for prosperity of Ethiopia, 16-18th May, 2012, Bahir Dar, Ethiopia, pp 54-58

Hu Z, Lane R, Wen Z (2008) Composting clam processing wastes in a laboratory- and pilot-scale in-vessel system. Waste Manag 29:180-185

Humphries EC (1956) Modern methods of plant analysis, vol 1. Springer, Berlin, pp 468-502

Jackson ML (1973) Soil chemical analysis. Prentice Hall, New Delhi

Kandari LS, Hiranmai YR, Thakur Ashok, Kandari Tripti (2014) Chat (Catha edulis): a socio economic crop in Harar Region, Eastern Ethiopia. Springerplus. doi:10.1186/2193-1801-3-579

Lohri CR, Camenzind EJ, Zurbrugg C (2014) Financial sustainability in municipal solid waste management-costs and revenues in Bahir Dar, Ethiopia. Waste Manag 34:542-552

Mahabub Y (2008) Composting of khat and related materials as solid waste management option in Awaday town. MSc thesis, Addis Ababa University

Manyuchi MM, Phiri A (2013) Vermicomposting in solid waste management: a review. Int J Sci Eng Technol 2:1234-1242 
Megerssa B, Esayas A, Mohamed A (2014) Socio economic impact of khat in Mana district, Jimma zone, South western Ethiopia. Discourse J Agric Food Sci 2:21-32

Mekonnen E, Argaw A (2015) Bioconversion of wastes (khat leaf left overs and eucalyptus twigs) into vermicompost and assessing its impact on potato yield. J Agron 14:37-42

Minaleshewa A, Chandrawanshi BS, Mesfin R (2010) Concentration levels of essential and non essential metals in Ethiopian khat (Catha edulis Forsk). Biol Trace Elem Res 138:316-325

Nagavellamma KP, Wani SP, Stephane L, Padmaja VV, Vineela C, Babu Rao M, Sahrawat KL (2004) Vermicomposting: recycling wastes into valuable organic fertilizer. Global theme on agroecosystems report no. 8, p 20

Parthasarathi K, Balamurugan M, Prashija KV, Jayanthi L, Basha SA (2016) Potential of Perionyx excavates (Perrier) in lignocellulosic solid waste management and quality vermifertilizer production for soil health. Int J Recycl Org Waste Agric 5:65-86

Pigatin LBF, Atoloye IA, Obikoya OA, Borsato AV, Rezende MOO (2016) Chemical study of vermicomposted agroindustrial wastes. Int J Recycl Org Waste Agric 5:55-63

Reda AA, Moges A, Biadgilign S, Wondmagegn BY (2012) Prevalence and determinants of khat (Catha edulis) chewing among high school students in Eastern Ethiopia: a cross sectional study. PLoS ONE 7:1-5

Regassa N, Rajan DS, Bizunesh BS (2011) Challenges and opportunities in municipal solid waste management: the case of Addis Ababa city, Central Ethiopia. J Hum Ecol 33:179-190

Taye HF, Jens BA (2003) Khat expansion in the Ethiopian highlands. Mt Res Dev 23:185-189

Telake (2007) The prevalence and risk factors of khat chewing among in school and out of school youth in Gonder town, Addis Ababa,
Ethiopia. The Ethiopian 10 years development plan, Addis Ababa, Ethiopia

Tiwari PK, Tiwari SC (2012) An overview of solid waste management system in Debre Markos town of Ethiopia. Glob J Curr Res $1: 1-8$

Tyagi V, Solomon F, Sharma HR (2014) Municipal solid waste management in Debre Birhan city of Ethiopia. J Environ Earth Sci 4:98-103

Vijayakumari B, Hiranmai YR (2004) Composting of poultry droppings with earthworm Eudrillus eugeniae. National seminar on "rural biotechnology for sustainable development" held at Gandhigram Rural Institute, Gandhigram, during 19-20th February 2004, abstract, pp 4-5

Vijayakumari B, Hiranmai YR (2005) Bioconversion of Parthenium hysterophorus as organic manure for chilli (Capsicum annuит L.). Indian J Environ Ecoplan 10:27-29

Wabel NT (2011) Psychopharmacological aspects of Catha edulis (khat) and consequences of long term use: a review. J Mood Disord 1:187-194

Walkley A, Black CA (1936) An examination of the Degtiareff method for determining soil organic matter and proposed modification of chromic acid titration method. Soil Sci 37:29-38

Wu L, Ma LQ (2001) Effects of sample storage on biosolids compost stability and maturity evaluation. J Environ Qual 30:222-228

Wu L, Ma LQ, Martinez GA (2000) Comparison of methods for evaluating stability and maturity of biosolids compost. J Environ Qual 29:424-429

Yeshigeta G, Abraham HM (2004) Khat chewing and its sociodemographic correlates among the staff of Jimma University. Ethiop J Health Dev 18:179-184 